DPST-76-221

\title{
PRELIMINARY I-129 MEASUREMENTS IN THE SRP ENVIRONS (U)
}

\section{WSRC Contact:}

W. H. Carlton

Westinghouse Savannah River Co.

Savannah River Site

Aiken, South Carolina 29808

A technical report being sent to OSTI and for distribution to the general public.

The information contained in this paper was prepared in connection with work done under Contract No. DE-AC09-76SR00001 with the U.S. Department of Energy. By acceptance of this paper, the publisher and/or recipient acknowledges the U.S. Government's right to retain a nonexclusive, royalty-free license in and to any copyright covering this paper, along with the right to reproduce and to authorize others to reproduce all or part of the copyrighted paper. 
C. 1i. Parterson -

H. A. McClearen

C. H. Ice -

L. H. Nejer - Sis

J. L. Crandall

H. J. Groh

L. W. Fox

J. M. Boswell

T. V. Crawford

E. B. Sheldon

W. L. Marter

E. T. Albenesius

UTS rile

Vital Records Copy

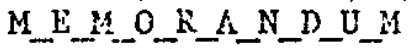

January 23, 1976

Fo: A. L. BONI

Frov: R. C. HOCHA $\therefore$. 4 .

\section{PRELIMINARY I-129 MEASUREMENTS IN THE SRP ENVIRONS}

\section{INTRODUCIION}

Recently a freliminary program was begun to measure I-129 concentrations in a variety of environmental samples. The objectives of the study were threefcld:.. First, to at least qualitatively estimate the impact of Savanah River Plant (SRP) operations on the I-129 inventory in the surrounding area; second, to determire prominent pathwsys of I-129 to man and to obtain, where possible,

itive estinates of their associated dose rates; and third, to provide iscessary input data to help in the design and implementation of more comprehensive Lollow-up studies.

Reasons for the recent increased interest in releases of I-129 to the environment and possible effects on man are evident from the following general comments.

Unlike I-131, : 129:s very long hali-life of $10^{7}$ years means that it poses a long term fotential lazard, particularly in view of the expanding nuclear power industry. As a beta emitter followed by only a weak $40 \mathrm{keV}$ gamina-ray, the primary hazari to man is thru ingestion with the thyroid being the critical organ since it contains aboul 20 percent of the body's total jodine. Prior to 1945 , I-129 corcentrations in soil, arisjrs from cosmic interact and

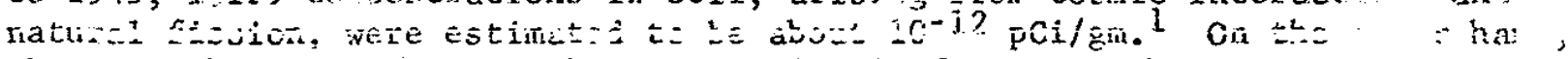
the contritution to present backgrcund levels fron atmospheric weap testing fallout is calculated to be about $1 \times 10^{-6} \mathrm{nCi} / \mathrm{gm}$ in soil, based on 1 . linjiorm deposition of 8.4 Ci. of $\mathrm{I}-120$ (40hCi/kt $\left.\times 2.2 \times 10^{5} \mathrm{kt}\right)$ over land and water j.n

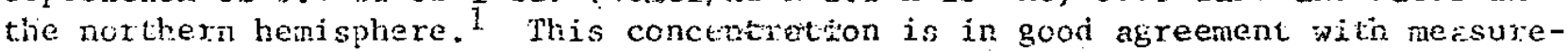
meits made by Bate? le Norkncet Laboratories (BNwL)l where levels arouid Horris, 
IIJinois vere found to be about $5 \times 10^{-6} \mathrm{poi} / \mathrm{gm}^{-6}$ in the top 1 -inch of soil.

Noting the ciramatic increase in $I-i 29$ backsround ievels caused by weapons testing: it is logical to investigate the cadiation dose-to-man titat might result from worli-wide nuclear fuel reprocessing. The eDvirons of SRP are a particularly valiable area for study because of the two decades of fuel reprocessing at this site.

\section{SUMMARY}

A preliminary program for measuring $I-129$ concentiations in various typcs of euviromental samples, including air, soil, vegetation, milk and deer thyroids, in an area extending to 100-miles from SRP has been completed. Measurenients were based on neutron activation analyses of iodine separated from these samples. 1

The technique involves separation of iodine by charcoal trapping following oxygen combustion of samples. Quartz ampoules containing iodine from samples aiva standards wexe irradiated in $\mathrm{K}$-Area reactcr. The irradiated iodine was separated from other activation products and counted on a Ge(Li) detector. Programs were written to use a programable calculator for direct reduction of the spectral data.

Measured I-129 concentrations in various types of samples were compared to dispersion model predictions. The agreement for air and soil samples was within a factor of five out to about 25-miles. Vegetation samples were within a factor of ten. In all cases measured values exceeded predicted values and agreement became worse with increasing distance from the plant. Within about a 25-mile radius of the plant, I-129 levels are expected to be noderatciy high and measured values should be fairly accurate. The overall good agreement between calculated and measured values in that area tends to support the vaiidity of the data. At greater distances, however, the larger discrepancies are attributed to sample contanination which was difficult to avoid with previous laboratory facilities, especially for vegetation. Efforts are presently underway to remedy this problem.

Averaged measured values for air, vegetation and miik samples, in the Plant: perimeter - 25 radius sector, were used to obtain human thyroid dose estimates for infants and adults from a critical pathway modei. The doses obtained for infants and adults were 0.30 and $3.95 \mathrm{mrem} /$ year respectively. A specific activity model gave 0.8 and $3.0 \mathrm{mren} /$ year based on $I-129 / I-127$ atcm ratios in infant and adult thyroid equal to the average found in on-plant deer.

This study was intended to be preliminary in nature and to give only a broad and cursory view of I-129 levels in the immediate area. Plans for a more conprehensive and in-depth study of I-129 in the environment are being developed.

\section{SAMPLE ANALYSIS}

\section{METHED}

Since tlse uptake of I-129 in man is governed by the ratio of radioactive to natural iodine in the environents that supply the sources of his hodily iodine, a method which could measure toth $I-129$ and nattral I-127 was needed. Neutron activation enalysis was found to be hest suited to this task since it allows both iodine concentrations to be measured, and provides the high sensitivity needcd for enviromental. samples.

Figure 1 shows a Iist of the reactions involved. The short half-life of I-128, from reaction 1 , requires that samples be countes within about $5-6$ hours

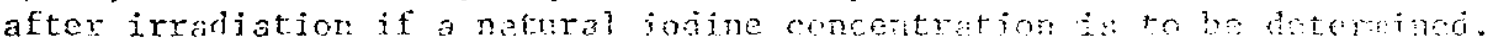


Reactions 1 and 2 are the heart of the methud since it is the comparison of I-128 and I-130 count rates in samples, with standards, which allows the I-127 and $\mathrm{I}-129$ concentrations in the samples to be calculated. As is lisualiy the case in activation analyses, scveral interfering reactions ( 3,4 and 5 ) can cause problems due to increased counting backgrounds. Reaction 3 can be minimized by using very small amounts ( $1 \mathrm{nCi}$ ) of $\mathrm{I}-125$, a tracer spike added to samples to dntermine chemical yield. Restion 4 is induced by fast nutcotis, and can best be avoided by irradiating samples in a flux with a high slow to fast neutron ratio. Since environmental smples usually contain a significant anount of bromine, reaction 5 can only be avoided thru chemical separation of iodine either before and/or after irradiation.

\section{PROCEDURE}

A simplified flow chart outlining the processing of sampies is shown in Figure 2. Samples are initially spiked with a known anount of I-125 wich is counted in the final step to determine the iodine chemical yield thru the procedure. Air samples are actually activated charcoal canisters which collect the iodine from a known amount of air. Soil and vegetation samples are dried initially while deer thyroids are analyzed on a wet-weight basis. Iodine from water and milk samples is collected on anion-exchange resin.

Samples or ion-exchange resin are then loaded into a quartz furnace tude and combusted in an $\mathrm{O}_{2}$ stream at $1000^{\circ} \mathrm{C}$. A charcoal trap following the furnace tube collects the lodine driven off the sample. This charcoal is inturn burned and the jodine trapped a second time on about $1.5 \mathrm{gm}$ of charcoal in a small diameter quartz tube. The tube is sealed at one end, evacuated, and then heated to drive the iodine off the charcoal to the sealed end of the tube which is immersed in liquid nitrogen. A second seal is then made to form an ampoule-about an jinch long containing the iodine.

Four sample ampoules and two containing I-127 and I-129 standards are welded into a single aluninum iriadiation capsule. Following irradiation for two hours at a thermal neutron flux of about $10^{14}$ in the K-Area rabbit, ampoules are renoved from the capsule and brought back to the laboratory for iodine separation from other activation products by multiple extractions into $\mathrm{CCl}_{4^{*}}$. Samples and standards are mounted on source cards as a AgI precipitate and then counted for $\mathrm{I}-128$ and $\mathrm{J}-130$ on a $\mathrm{Ge}(\mathrm{Li})$ detector in a low-level counting facility. After a several day decay period, a low-energy photon detector is used to count the I-125 spike for a yield determination.

\section{DATA REDUCLION}

To facilitate handing and reducing the data, programs were written to utilize a programable calculator interfaced directly to the matichannel. analyzer uscer to accunulate the iodine sar.iz spectra. An example of tyrical

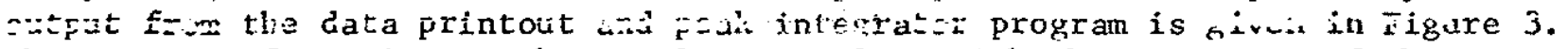
The operator fir,t inputs the sample name along with the times out of the reactor and counted so t.lat decay corrections can be made. Next the channel numbers in 
which the analytical peaks for $I-128$ and $I-130$ are to bo found are assigred. The calcuiator then prints these channels, followed by a request for an energy siope factor. After the value is input, the caiculato echor it ind princs the resujts of the peak integrations. The peak at $443 \mathrm{keV}$ belongs to I-128 as does the snaller one at $527 \mathrm{keV}$. The $536 \mathrm{keV}$ peat beiongs to I-130.

After the above progrem is run for all four samples and the two standarde, and the I-125 values are obtained in a similar way, the data is input into a second program as shown in Figure 4. The calculator asks for the sample nane and values for courts/nin and sigma for $I-125, I-128$ and $I-130$, echoing them as they are input. The program then prints out the yield and corrected count rates for I-128 and I-130. After this is done for the samplen and stand-axds, the calculator again asks for a sample name and samile size, and then calculates the $\mu \mathrm{g}$ of $\mathrm{I}-127$ and I-129 along with the PCi of I-129 and the I-129/ I-127 atom ratio in the sample.

\section{RESULTS}

\section{F and $\mathrm{H}$ STACK AIRS}

Measurements of I-129 concentrations released to the atmosphere by the separations areas were obtained from anaiyses of one-week long primary and back-up charcoal canisters routinely taken by Health Physics personie1. The total I-129 concentrations are summarized in Table 1. The data. for the various months are really only a reflection of a single weeks' activity in that month, and can oniy be expected to average-out over a number of months. Hence extrapolated values at the bottom of the table should be viewed as order-oi-magnitude type numbers.

Estimated releases for 1975 were not available at the time of this writing. The lower extrapoluted tota1 I-129 concentrations measured for 1975 compared with the estimated 1974 concentration reflect the reduced operations in one of the separations axeas during the year.

\section{AIR and SOIL}

To interpret the other data obtained in this study, dispersion models which predict desired air concentrations based on meteorlogical conditions and known source terms were used. One such model developed by R. E. Cooper, ${ }^{2}$ here at SRL, utilizes known average veather conditions for the plant and surrounding area to calculate $X / Q$, or concentration per unit source values at various distances from the stacks. Multipling these values by the estimated stack release rates, gives air concentrations at specified distances which can be compared with measured values. Sinilarly, once air concentrations are known, one has only to multiply by an appropriate iodine deposition velocity and total exposure time to determine soil concentrations.

A comparison between calculated and measured air and soil I-129 concentrations at various distances from the stacks is shown in Table 2. The comparison is quite good witl the single exception of air at 100 miles where the measured value is high by about a factor of 40 . It is suspected that this is due to a contamination problen associated with handling low-level samples in the laboratory where I-129 air concertrations are noderately high. However, agrcement between air samples can be expected to be scmewhat poorer since one is 
comparirg short term measurements with long tem average caicujations,

\section{VEGETAIION}

Extending such wodel calculations along the ecological wain to vegetation cán be done, but results are less relisble sirce each step in the chain introdices additional parameters, which in general can only be estimated. A better approacin is to use a meastred transierence number which relates vegetation to air coricen-

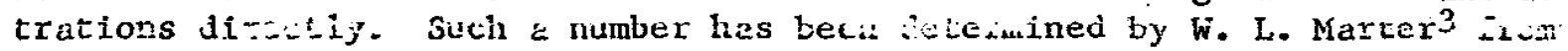
studies nade following the 1961 SRP I-131 release.

The compaison between calculated and measured $1-129$ values in vegetation samples is given in Table 3. Calculated values are based on the meastired tranference number, determined by Marter, and the model predicted air concentrations at the specified distances. While agreement is not as good as it was with air and soil, neither is the overall quality of the data. Calculated values are more assumptive by nature and the potential for sample contamination, which has been attributed as the cause of the 1 arge discrepancy at 100 miles, is more likely in view of vegetations' large affinity for airborneiodine.

\section{MILK}

Insufficient data were available to attempt similar comparisions for milk, since neither samples of actual. cattle forage nor specific information on dietary make-up was.sought in this preliminary study. However, milk samples were classified as originating from single cows or dairies, and it was found that in general I-129 coicentrations in milk from single cows were higher. This of course is reasonable since singie cows are mostly on pasture whereas dairy cattls usually receive supplimental feed.

Dairy milk samples, all from within a 25 -mile radius of the plant, had an average $I-129$ concentration of $6 \times 10^{-2} \mathrm{pCi} / 1$, while the highest value, that from a single cow near the plant perimeter, was $9 \mathrm{pCi} / 1$. This shows there is a wide variation in milk values, but all are well below the ERDA RCG value of $60 \mathrm{pCi} / 1$ for water.

\section{DOSE ESTTMATES}

Using the average measured values for $I-129$ concentrations in various types of samples in the plant perimeter - 25 mile radius sector, human thyroid dose estimates were obtained from a critical pathway model for both infants and adults. (For a detailed discussion of this model and methods of dose calculations see Reference 4.)

Results are summarized in Table 4. Values are based on assumed thyroid masses of $2 \mathrm{gm}$ for infants and $20 \mathrm{gm}$ for adults along with the expected average intake rates via the pathways shown at the bottom of the Table. The major pathway for adults efpecirs to be thru leafy vege+ohlas, phereas nomally milk is cursitered

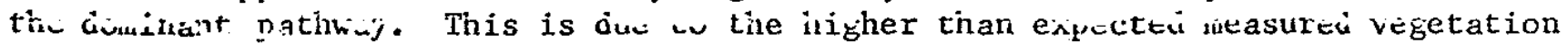
values noted above. In any event, the totals of 0.30 and $3.95 \mathrm{mrem} /$ year are small compared to the revised limits cited in Technical Standard DPSTS-RH-W-0.1 (30 mrem/ year).

As a footnote: a worst-case upper limit to the dose rates in Table 4 can be cbtained from a specific activity mode $1^{4}$ if one assumes that the average I-129/I-127 atom ratio, from measurements of on-plant deer thyroids, is not: likely to be exceeded in man residing off-plant. Sixteen onmplant deer thyroid samples were analyzed. The, average I-1.29/I-127 ratio was $4.2 \times 10^{-5}$. An outline of the calculations and the results of the model estimates are shown in 


\section{REERENCES}

1. J. K. Soldat Et Al., "The Radioccology of Icdine-129." An Inctin Keport, USAEC Report BNWL-1783, BatteIle Memcrial Institute, Pacific Northwest Laboratories, September, 1973.

2. R. F. Cooper, "Computer Programs at SRL to Evaluate Environmental Fffects of SRP Operations and Postulated Accidental Releases." DPST-75-384 (19.75).

3. W. L. Marter, "Radioiodine Release Incident at the Savannal River Plant." Health Phy., 9:1105-1109 (1963).

4. J. Mo Palms Et Al., "The Envirommental Tmpat ${ }^{129}$. Released by a Nuclear Fuel Reprocessing Plant." Nucl. Safety, 16-5: 593-602 (1975). 
TABLE 1

\section{MEASURED I-129 STACK RELEASES}

Month/Year

$01 / 75$

$02 / 75$

$03 / 75$

$04 / 75$

$05 / 75$

$05 / 75$

$07 / 75$

$08 / 75$

1975 Total To Date

1975 Extrapolated

1974 Estimated
I-129(mCi)

2.9

2.1

3.3

5.6

$\dot{x}$

2.7

$*$

\begin{tabular}{l}
5.6 \\
\hline 22.2
\end{tabular}

170

\footnotetext{
$\%$ Not measured.
} 


\section{COMPARISON OF MFASURED AND CALCULATED I-129 CONCENIRATIONS}

\section{IN AIR AND SOTh}

Distance

Plant Perimeter

25 Mile Radius

100 Mile Redius
Soil (pCi/gin)*

$1.1 \times 10^{-3}$

$3.1 \times 10^{-a}$

$3.1 \times 10^{-4}$
Soi1 (pCi/gra)

$2.1 \times 10^{-2}$

$5.0 \times 10^{-3}$

$1.0 \times 10^{-3}$

\section{$\operatorname{Air}\left(\mathrm{pC}_{i} / \mathrm{m}^{\mathrm{j}}\right)^{*}$}

$4.7 \times 10^{-6}$

1. $3 \times 10^{-5}$

$1.3 \times 1.0^{-6}$
$6.5 \times 10^{-5}$

$5.6 \times 10^{-5}$$$
\text { . }
$$

$\operatorname{Air}\left(\mathrm{CC}_{\mathrm{i}} / \mathrm{m}^{3}\right)$

$5.7 \times 10^{-6}$

* Calculáted values. 


\section{TABIE ?}

\section{COMPARISON OF MEASURED AND CALCUIATED I-129 CONCENTRATIONS}

\section{IN VEGETATION}

Distance

P1ant perimeter

25 Miles Radius

100 Miles Radius
Calculated (pCi/g Dry)

$$
2 \times 10^{-3}
$$

$5 \times 10^{-4}$

$5 \times 10^{-5}$
Measured ( $\mathrm{pC} i / \mathrm{g}$ Dry)

$$
9 \times 10^{-2}
$$

$4 \times 10^{-3}$

$5 \times 10^{-3}$ 


\section{TABLE}

\section{ANNUAL THYROID DOSES FROM VARIOUS PATHWAYS}

\section{Dose (mrem/year)}

Pathway Infant Adult

Irinalation

$1.4 \times 10^{-3}$

$2.5 \times 10^{=3}$

\section{Ingestion}

Via Milk*

0.30

0.15

Via Leafy Vegetables**

\begin{tabular}{c}
0 \\
$0.30 \quad 3.30$ \\
\hline 3.95
\end{tabular}

TOIAL

0.30

3.95

* Based on 1 liter/day local dairy milk @ $5.5 \times 10^{-2} \mathrm{pCi} / 1$.

$\therefore$ Based on $73 \mathrm{~kg} /$ year leafy vegetables a $7 \mathrm{pCi} / \mathrm{kg}$. 
LIST OF REACTTONS INVOLVED TN NEUTRON ACTTVATION SNALYSTS OF IODNIE SAMPLES

PERTINENT REACTION FOR TODINE ACTIVIATION ANALYSIS

1) ${ }^{127} \mathrm{I}(\mathrm{n}, \gamma){ }^{123} \mathrm{I} \rightarrow{ }^{128} \mathrm{Xe}$

2). ${ }^{129} \mathrm{I}(\mathrm{n}, \gamma){ }^{130} \mathrm{I} \rightarrow{ }^{130} \mathrm{Xe}$

$t_{\frac{1}{2}}=25$ min.

$t_{\frac{1}{2}}=12.4 \mathrm{hr}$.

\section{INTEKFERING REACTIONS}

3) ${ }^{125} \mathrm{I}(\mathrm{n}, \mathrm{y}){ }^{126} \mathrm{I} \rightarrow{ }^{126} \mathrm{Xe}$

$t_{\frac{3}{2}}=13 \mathrm{~d}$

4) ${ }^{127} I\left(n, 2 n ;{ }^{126} I \rightarrow 1^{126} X e\right.$

5) $81_{\mathrm{Br}}(\mathrm{n}, \gamma){ }^{82_{\mathrm{Br}}}+{ }^{82_{\mathrm{Kr}}}$

$t_{\frac{3}{2}}=36 \mathrm{hr}$.

FIGIPp: 1 
- A. L. Bou $\quad * \quad-12$.

FLOW SCHEME FOR I-127, 129 SAIPIS ANAIYSIS

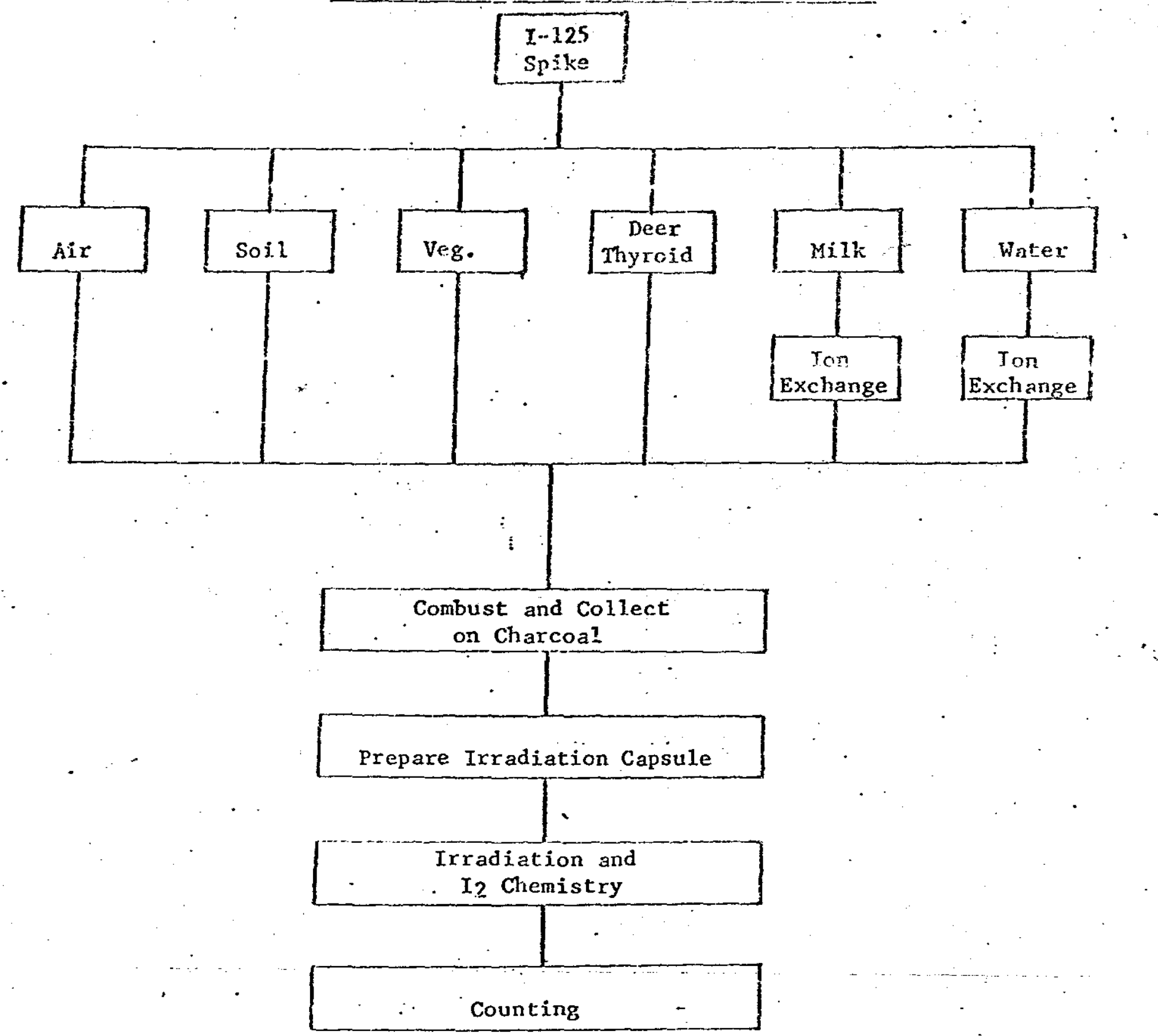

FIGURE 2 
1., L. Moni

X-229, SERIES *348, SAMPLE \#4

TULE OUT 07/08/75/68/28

COUNTED 07/C8/75/14;07

TYPICAL OUTPUT EROM DATA PRISTOUY AND PEAK

Iiv'EGRATOR POOCNAI

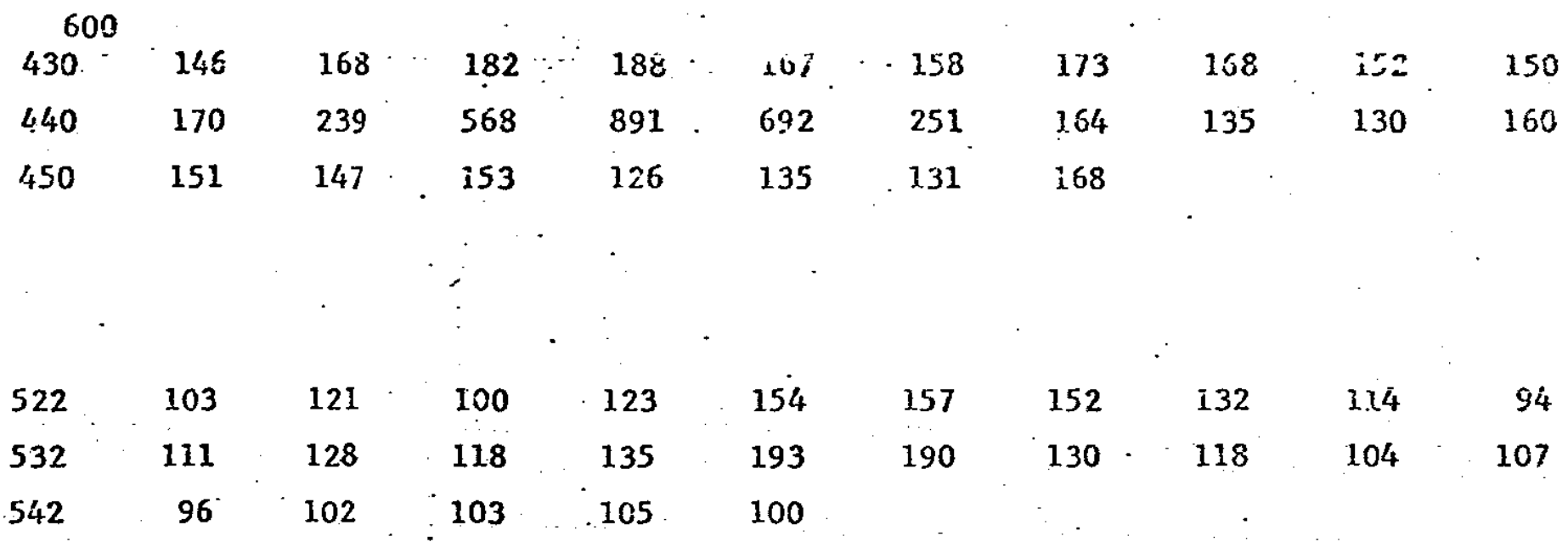

$\mathrm{KEV} / \mathrm{CH}$.

1.0000

PEAK INTEGRATOR

COUNTING TIME

600.0000

ENERGX

COUNTS/MIN.

443.0437

193.0833

SIGMA

6.3397

ENERGY

COUNTS/MIN.

SIGMA

527.4303

17.5000

3.8588

ENEKGY

COINTS/MIN:

SIGMA

536.4898

24.4000

3.9038 
SAMPIE NA:UE

$355-2$ TYPICAL OUTYUI FROM IODIME DATA REDUCTION FROCPU

ENTER C/M $T-125$

3. $06,6000000+02$

ENTER SIGMA

$1.460000000 \div 01$

ENTER C/M $\chi-128$

$4.048028800+07$

ENTER SIGIA

$1.767774000+06$

ENTER $C / M I-130$

$1.000700000+0$ :

ENTER SIGMA

$\begin{array}{cc}\text { YIELD }= & \begin{array}{c}3.470000000+02 \\ \text { tCR- }\end{array} \\ 1.3535488513134-01\end{array}$

$x-128=$

$1.157964870+08$

$+\mathrm{OR}-$

$6.758231069+06$

$\mathrm{I}-130=$

$2.862567196+04$

+OR

$1.487868144+03$

SAYPLE NAME

$355-2$

INTER SAMFLE SJZE

2.125000000400

$\begin{array}{ll}\text { UG I-127 } & =\quad 1.253631260+01 \\ \text { +OR- } & 8: 304983388-01\end{array}$

UG $I-129=4.583760353-03$

tOR- 2.664935:99-04

PCI $x-129=1.639600589-01$

tOR- $4.441560831-02$

RATIC $I-129 / I-127=\quad 3.656386450-04$

+OR- $\quad 3.222772565-05$ 
I-129/T-127 ON-PLANO DEER IHYROTDS $=4.2 \times 10^{-5}$

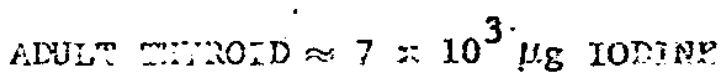

$$
\begin{aligned}
& 4.2 \times 20^{-5} \times 7 \times 10^{3}=0.29 \mu \mathrm{g} \quad-129 \\
& \text { THXROID DOSE RATE }=3 \mathrm{MREM} / \mathrm{YR}
\end{aligned}
$$

INFANT THYROTD $\approx 1.8 \times 10^{2} \mu \mathrm{g}$ IODTHE

$4.2 \times 10^{-5} \times 1.8 \times 10^{2}=7.6 \times 10^{-3} \mu_{g}$ I-129. THYROID DUSE RATE $=0.8 \mathrm{MREM} / \mathrm{YR}$ 